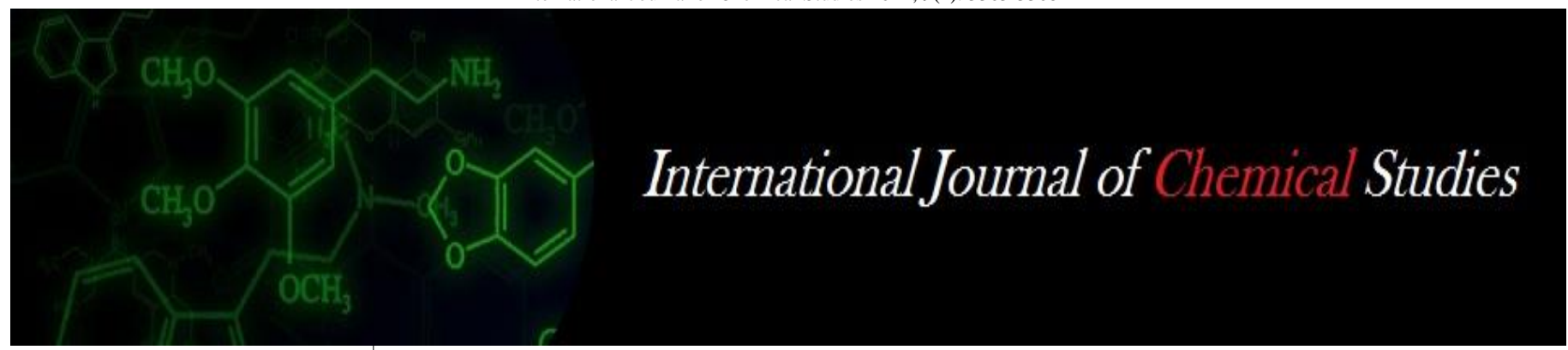

P-ISSN: 2349-8528

E-ISSN: 2321-4902

www.chemijournal.com

IJCS 2021; 9(1): 3363-3368

(C) 2021 IJCS

Received: 24-10-2020

Accepted: 30-12-2020

SV Pimpale

College of Agricultural

Engineering and Technology,

VNMKV, Parbhani,

Maharashtra, India

AS Kadale

AICRP on Irrigation Water

Management, VNMKV,

Parbhani, Maharashtra, India

GD Gadade

AICRP on Irrigation Water

Management, VNMKV,

Parbhani, Maharashtra, India

BW Bhuibhar

College of Agricultural

Engineering and Technology,

VNMKV, Parbhani,

Maharashtra, India

AM Kamble

AICRP on Irrigation Water

Management, VNMKV,

Parbhani, Maharashtra, India

Corresponding Author:

SV Pimpale

College of Agricultural

Engineering and Technology,

VNMKV, Parbhani,

Maharashtra, India

\section{Influence of different mulches and irrigation \\ levels on water use efficiency, weed biomass and productivity of drip irrigated tomato (Lycopersicum esculentum Mill.)}

\author{
SV Pimpale, AS Kadale, GD Gadade, BW Bhuibhar and AM Kamble
}

DOI: https://doi.org/10.22271/chemi.2021.v9.i1au.11757

\begin{abstract}
The field experiment was conducted at the research farm of AICRP on Irrigation Water Management, Vasantrao Naik Marathwada Krishi Vidyapeeth, Parbhani to study the influence of different mulches and irrigation levels on water use efficiency, weed biomass and productivity of drip irrigated tomato (Lycopersicum esculentum Mill.) during rabi season of 2016-17 and 2017-18. The experiment was laid out in a split plot design replicated thrice with twelve treatments combination comprising of three irrigation regimes viz. irrigation level at $0.6 \mathrm{PE}\left(\mathrm{I}_{1}\right)$, irrigation level at $0.8 \mathrm{PE}\left(\mathrm{I}_{2}\right)$ and irrigation level at 1.0 PE $\left(\mathrm{I}_{3}\right)$ in main plot and four polythene mulch treatments viz. black polythene mulch $\left(\mathrm{M}_{1}\right)$, silver black polythene mulch $\left(\mathrm{M}_{2}\right)$, transparent polythene mulch $\left(\mathrm{M}_{3}\right)$ and control $\left(\mathrm{M}_{4}\right)$ in sub plot. The results revealed that the application of drip irrigation at $0.6 \mathrm{PE}$ and silver black polythene mulch recorded higher water use efficiency due to lower consumption of irrigation water. Use of silver black polythene mulch or black polythene mulch with drip irrigation at $0.6 \mathrm{PE}$ inhibited weed growth throughout growing period of tomato. The treatment combination of drip irrigation level at $0.8 \mathrm{PE}$ with silver black polythene mulch $\left(\mathrm{I}_{2} \mathrm{M}_{2}\right)$ recorded higher yield attributes along with higher fruit yield of tomato over rest of the treatment combination, however it was comparable with treatment combination of irrigation level at $0.8 \mathrm{PE}$ with black polythene mulch $\left(\mathrm{I}_{2} \mathrm{M}_{1}\right)$ and irrigation level at $0.6 \mathrm{PE}$ with silver black polythene mulch $\left(\mathrm{I}_{1} \mathrm{M}_{2}\right)$.
\end{abstract}

Keywords: Tomato, water use efficiency, weed, drip irrigation, mulches and yield

\section{Introduction}

India has one of the highest water usage for agriculture in the world - of the total 761 billion cubic meter (bcm) withdrawals of water, $688 \mathrm{bcm}$ (90.5 percent) goes into agriculture. China uses $385.2 \mathrm{bcm}$ (64.4 percent) out of total withdrawals of $598.1 \mathrm{bcm}$ for agriculture.

Sustainable development and efficient water management is an increasingly complex challenge in India. Agriculture in Marathwada region is mainly rainfed with only 12 percent area under irrigation. The average annual rainfall of this region is as low as $779 \mathrm{~mm}$ with $40 \%$ drought prone area. Water conservation is a major element of any strategy that aims to alleviate the water scarcity crisis. This can be achieved by introducing advanced methods of irrigation and improved water management practices.

Water saved from drip irrigation system is varied from 12 to 84 percent for different crops with enhancement of crop production. It provides significantly higher water usage efficiency due to proximity and focused application. Polyethylene mulching coupled with drip irrigation system is effective method to produce the 'Per Drop More crop' to conserve soil and water. Now a days use of polyethylene mulch becomes standard practice for all vegetable farmers. It's main advantage consists of not only to reduce application of water and fertilizers but also to increase crop production and suppress weed growth.

Considering above aspects, the present field experiment was conducted to study influence of different mulches and irrigation levels on water use efficiency, weed biomass and productivity of drip irrigated tomato (Lycopersicum esculentum Mill.) in Marathwada region of Maharashtra. 


\section{Materials and Methods}

Experimental site: The field experiment was conducted during rabi season of 2016-17 and 2017-18 at the research farm of All India Co-ordinated Research Project on Irrigation Water Management, Vasantrao Naik Marathwada Krishi Vidyapeeth, Parbhani which lies between $19^{\circ} 16^{\prime} \mathrm{N}$ latitude and $76^{\circ} 47^{\prime} \mathrm{E}$ longitude with an altitude of $409 \mathrm{~m}$ above the mean sea level.

Experimental details: The field experiment was laid out in split plot design with twelve treatment combinations which replicated thrice presented in fig 1 . The main plot treatments comprised of three irrigation regimes viz. irrigation level at $0.6 \mathrm{PE}\left(\mathrm{I}_{1}\right)$, irrigation level at $0.8 \mathrm{PE}\left(\mathrm{I}_{2}\right)$ and irrigation level at 1.0 PE $\left(\mathrm{I}_{3}\right)$ and four polythene mulch treatments viz. black polythene mulch $\left(\mathrm{M}_{1}\right)$, silver black polythene mulch $\left(\mathrm{M}_{2}\right)$, transparent polythene mulch $\left(\mathrm{M}_{3}\right)$ and control $\left(\mathrm{M}_{4}\right)$ were assigned to sub plots. Thirty days old healthy tomato seedlings of variety Namdhari NS-629 were transplanted at 60 $\mathrm{cm} \times 60 \mathrm{~cm}$ on broad bed furrow during both study years.

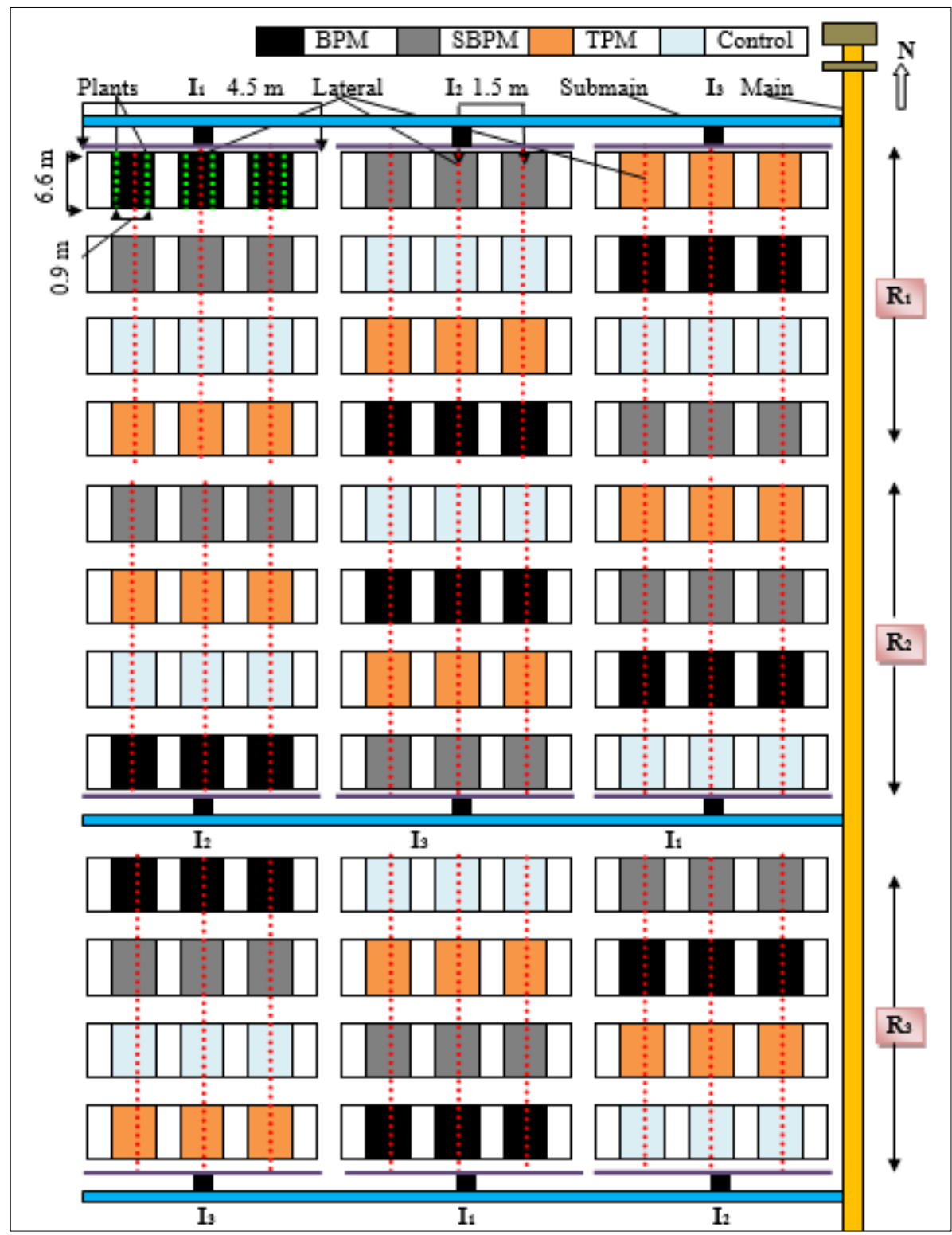

Fig 1: Layout of Experimental Field

Irrigation scheduling: The irrigation was scheduled as per predefined treatment at alternate days based on cumulative pan evaporation through drip irrigation method. The treatment wise quantity of water to be applied at alternate day was estimated by considering cumulative daily pan evaporation for two days and area to be irrigated. The following formula was used for evaluating the quantity of water applied.

$\mathrm{V}=\mathrm{PE} \times \mathrm{A}$

Where, $\mathrm{V}=$ Volume of water to be applied (litre)

$\mathrm{PE}=$ Daily cumulative pan evaporation $(\mathrm{mm})$ multiplied by factor of irrigation regimes i.e. 0.6, 0.8 and 1.0
$\mathrm{A}=$ Unit area of plot $\left(\mathrm{m}^{2}\right)$

The operating time of drip system (t) was calculated by using the following formula.

$\mathrm{t}=\frac{\mathrm{V}}{\mathrm{q} \times \mathrm{Ne}} \times 60$

Where, $\mathrm{t}=$ time of operating system $(\mathrm{min})$

$\mathrm{q}=$ Average emitter discharge (lph)

$\mathrm{Ne}=$ Number of emitter per unit length of lateral 
Observation details: The water use efficiency (WUE) i.e per $\mathrm{kg}$ yield of tomato fruits per mm of water per hectare in each treatment plot was determined by using following formula.

$$
\operatorname{WUE}(\mathrm{kg} / \mathrm{ha}-\mathrm{mm})=\frac{\text { Average yield }(\mathrm{kg} / \mathrm{ha})}{\text { Amount of applied water }(\mathrm{mm})+\text { Effective rainfall }}
$$

Numbers of weed were counted in $1.0 \mathrm{~m}^{2}$ area from each treatment plot at harvesting by using quadrant. Similarly, the weed dry weight recorded from each treatment plot at harvesting expressed in gram per sq. meter. The number of fruits per plant was counted at each harvesting from five observational plants and after last harvesting average number of fruit per plant was determined. The fruit yield from the five observation plants at each harvesting from each treatment plot was recorded separately and the average yield per plant was worked out. Treatment wise fruit yield of tomato from each treatment plot was recorded at time of harvesting and converted into tonne per hectare. The data on yield and yield attributing characters of tomato and weed observations were subjected to statistical analysis of variance technique. The pooled analysis of tomato yield and yield attributing characters of tomato for two years was work out as per method described by Gomez and Gomez, 1984.

\section{Results and Discussion \\ Water use efficiency}

Data pertaining to water use efficiency and total water use for tomato crop influenced by different irrigation regimes and mulches are presented in Table 1 and shown in Fig. 2.

Table 1: Water use efficiency $(\mathrm{Kg} / \mathrm{ha}-\mathrm{mm})$ of drip irrigated tomato as influenced by different irrigation regimes and mulches during 2016-17 and $2017-18$

\begin{tabular}{|c|c|c|c|c|}
\hline Treatment & \multicolumn{2}{|c|}{ Total water use (mm) } & \multicolumn{2}{c|}{ Water use efficiency (Kg/ ha- mm) } \\
\hline Irrigation regimes & $\mathbf{2 0 1 6 - 1 7}$ & $\mathbf{2 0 1 7 - 1 8}$ & $\mathbf{2 0 1 6 - 1 7}$ & $\mathbf{2 0 1 7 - 1 8}$ \\
\hline $\mathrm{I}_{1}-0.60 \mathrm{PE}$ & 441.12 & 403.39 & 266.88 & 263.98 \\
\hline $\mathrm{I}_{2}-0.80 \mathrm{PE}$ & 588.16 & 534.67 & 232.50 & 225.02 \\
\hline $\mathrm{I}_{3}-1.0 \mathrm{PE}$ & 735.20 & 665.95 & 165.58 & \\
\hline Mulches $_{\mathrm{M}_{1}=\mathrm{BPM}}$ & & & & \\
\hline $\mathrm{M}_{2}=\mathrm{SBPM}$ & 588.16 & 534.67 & 235.57 & 234.92 \\
\hline $\mathrm{M}_{3}=\mathrm{TPM}$ & 588.16 & 534.67 & 256.70 & 242.08 \\
\hline $\mathrm{M}_{4}=$ Control & 588.16 & 534.67 & 190.62 & 198.47 \\
\hline
\end{tabular}

The total amount of irrigation water applied for tomato plants as per predefined treatments varied from $441.12 \mathrm{~mm}$ to $735.20 \mathrm{~mm}$ during 2016-17 and $403.30 \mathrm{~mm}$ to $665.95 \mathrm{~mm}$ during 2017-18.

The highest amount of irrigation water was applied in irrigation level at 1.0 PE followed by irrigation level at 0.8 PE while lowest amount of irrigation water was applied in irrigation level 0.6 PE during both growing seasons. Data indicated that highest water use efficiency (266.88 and 263.98 $\mathrm{Kg} / \mathrm{ha}-\mathrm{mm}$ ) for tomato recorded in lower application of irrigation i.e irrigation level at $0.6 \mathrm{PE}$, while lower water use efficiency $(165.58$ and $168.82 \mathrm{Kg} / \mathrm{ha}-\mathrm{mm})$ observed in irrigation level at 1.0 PE during both the year of study. It is evident from data that water use efficiency increases with reducing amount of irrigation water applied throughout growing period of tomato crop. This might be due to better utilization of irrigation water throughout the growing period of tomato which reflected in better yield and yield attributes.
In case of various mulches, the mean of the imposed irrigation treatments was $588.16 \mathrm{~mm}$ and 534.67 during 2016-17 and 2017-18 respectively. The highest water use efficiency ( 256.70 and $242.08 \mathrm{Kg} / \mathrm{ha}-\mathrm{mm}$ ) was recorded in silver black polythene mulch which followed by black polythene mulch (235.57and $234.92 \mathrm{Kg} / \mathrm{ha}-\mathrm{mm}$ ) during both growing seasons. However the lowest water use efficiency recorded in control (169.97and $171.13 \mathrm{Kg} / \mathrm{ha}-\mathrm{mm}$ ) during both the years of study. The probable reason for this might be that drip irrigation with polythene mulch provide adequate amount of irrigation water in vicinity of plant root zone and reducing rate of evaporation which developed better soil-water- plant relationship for tomato crop. Choudhary and Bhambri (2013) ${ }^{[2]}$ also reported similar results for capsicum that drip irrigation at 0.6 Epan with black polythene mulch resulted highest water use efficiency over rest of treatment. The present results are in agreement with finding reported by Kashyap et al. (2009) ${ }^{[5]}$, Yaghi et al. (2013), Reddy et al. (2015) ${ }^{[8]}$, Paul et al. (2015), Singh et al. (2009) ${ }^{[9]}$, Job et al. (2018) ${ }^{[4]}$.

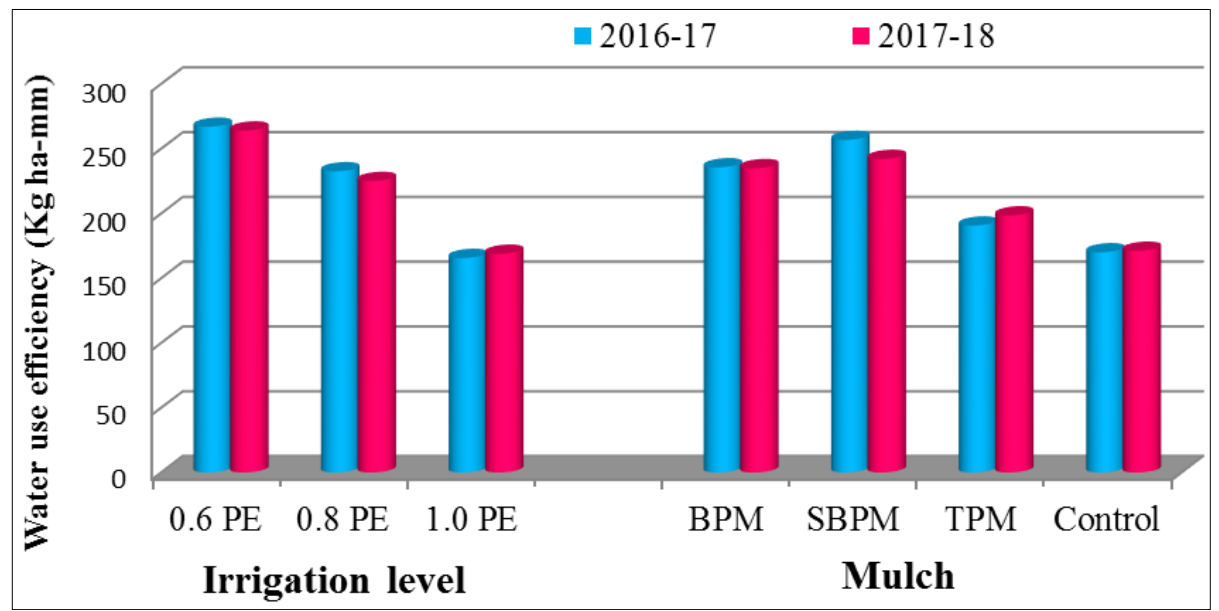

Fig 2: Water use efficiency as influenced by different irrigation regimes and mulches during 2016-17 and 2017-18 $\sim 3365 \sim$ 
It is apparent from Fig. 2 that the water use efficiency increased with reducing irrigation water and it was maximum in irrigation at $0.6 \mathrm{PE}\left(\mathrm{I}_{1}\right)$ and among mulches it was higher in silver black polythene mulch during 2016-17 and 2017-18.
Weed density and weed dry weight: The results presented in Table 2 revealed that weed density and weed dry weight were influenced significantly by different irrigation regimes and mulches during both the years of study.

Table 2: Weed density and weed dry weight as influenced by different irrigation regimes and mulches during 2016-17 and 2017-18

\begin{tabular}{|c|c|c|c|c|}
\hline \multirow{2}{*}{$\begin{array}{c}\text { Treatment } \\
\text { Irrigation regimes }(\mathrm{I})\end{array}$} & \multicolumn{2}{|c|}{ Weed density (plant/ $\mathbf{m}^{2}$ ) } & \multicolumn{2}{|c|}{ Weed dry weight $\left(\mathrm{gm} / \mathrm{m}^{2}\right)$} \\
\hline & 2016-17 & 2017-18 & 2016-17 & 2017-18 \\
\hline $\mathrm{I}_{1}=0.6 \mathrm{PE}$ & 68.25 & 70.83 & 33.08 & 37.42 \\
\hline $\mathrm{I}_{2}=0.8 \mathrm{PE}$ & 81.67 & 91.17 & 42.67 & 51.92 \\
\hline $\mathrm{I}_{3}=1.0 \mathrm{PE}$ & 93.92 & 116.50 & 53.67 & 60.17 \\
\hline S.E. \pm & 3.96 & 3.87 & 2.13 & 2.52 \\
\hline C.D. $(\mathrm{P}=0.05)$ & 11.00 & 10.74 & 5.92 & 7.01 \\
\hline \multicolumn{5}{|l|}{ Mulches (M) } \\
\hline $\mathrm{M}_{1}=\mathrm{BPM}$ & 15.22 & 20.67 & 13.44 & 15.11 \\
\hline $\mathrm{M}_{2}=\mathrm{SBPM}$ & 12.00 & 9.11 & 7.56 & 12.33 \\
\hline $\mathrm{M}_{3}=\mathrm{TPM}$ & 89.78 & 126.56 & 59.11 & 68.78 \\
\hline $\mathrm{M}_{4}=$ Control & 208.11 & 215.00 & 92.44 & 103.11 \\
\hline S.E. \pm & 8.25 & 14.89 & 7.28 & 8.25 \\
\hline C.D. $(\mathrm{P}=0.05)$ & 17.34 & 31.28 & 15.29 & 17.34 \\
\hline \multicolumn{5}{|l|}{ Interaction(I x M) } \\
\hline S.E. \pm & 14.30 & 25.79 & 12.60 & 14.30 \\
\hline C.D. $(\mathrm{P}=0.05)$ & NS & NS & NS & NS \\
\hline
\end{tabular}

The results indicated that the application of irrigation at 1.0 $\mathrm{PE}\left(\mathrm{I}_{3}\right)$ was recorded significantly higher weed density and weed dry weight during both growing seasons. The minimum weed density and weed dry weights were observed in irrigation level at $0.6 \mathrm{PE}\left(\mathrm{I}_{1}\right)$ during both the years of study. This might be due to availability of optimum irrigation water leading to increased weed population as well as weed dry weight which reflected lower fruit yield in irrigation level at 1.0 PE $\left(\mathrm{I}_{3}\right)$. The present results are in agreement with the finding of Kishore et al. (2018) ${ }^{[6]}$.

The results with respect to different mulches revealed that the silver black polythene mulch recorded significantly minimum weed density and weed dry weight as compared to rest of mulches while it was found at par with black polythene mulch during 2016-17 and 2017-18 respectively. However higher weed density and weed dry weight was recorded in control treatment followed by transparent polythene mulch during both years of experimentation. The black polythene mulch and silver black polythene mulch reduced transmission of light and also reflects incoming solar radiation resulted in lower weed infestation only through the punch while transparent polythene mulch had heavy weed infestation due to high light transmission. The black polythene mulch and silver black polythene blocked the weed growth, except a few, which emerged through the planting holes. The polythene mulch inhibited weed growth reflecting in enhancing fruit yield of tomato. Similar kind of results were obtained by Rajablariani et al. (2012) ${ }^{[10]}$, Sun et al. (2015), Kishore et al. (2018) ${ }^{[6]}$ and Ashrafuzzaman et al. (2011).

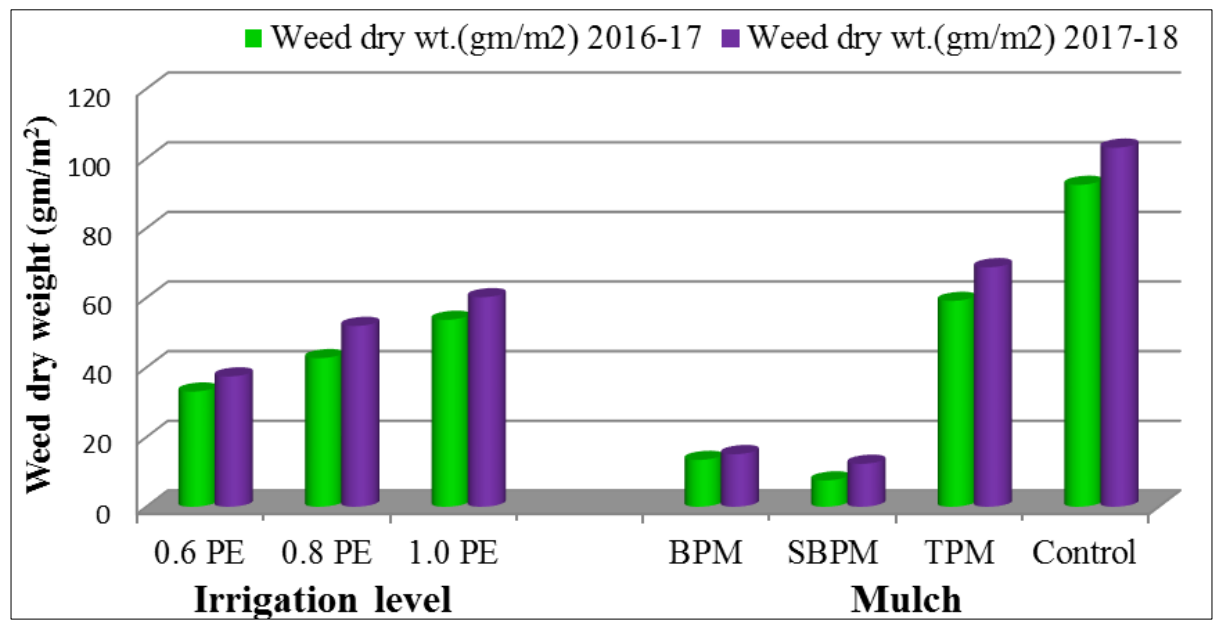

Fig 3: Weed dry weight as influenced by different irrigation regimes and mulches during 2016-17 and 2017-18

It is apparent from Fig 3 that among different irrigation regimes and mulches, weed dry weight was higher in irrigation level at 1.0 PE and control treatment during both study years.

\section{Interaction effect}

The interaction effect of different irrigation regimes and mulches on weed density and weed dry weight was found non significant during both the years of experimentation.

\section{Yield and yield attributing characters}

The data furnished in Table 3 revealed that effect of different irrigation regimes and mulches on number of fruit per plant, yield per plant and fruit yield was found significant during both the years of experimentation. 
Table 3: Yield and yield attributing characters in drip irrigated tomato as influenced by different irrigation regimes and mulches during 2016-17 and 2017-18

\begin{tabular}{|c|c|c|c|c|c|c|c|}
\hline \multirow{2}{*}{$\begin{array}{c}\text { Treatment } \\
\text { Irrigation regimes (I) }\end{array}$} & \multicolumn{2}{|c|}{ Number of fruits per plant } & \multicolumn{2}{|c|}{ Yield per plant (Kg) } & \multicolumn{3}{|c|}{ Fruit yield (t/ha) } \\
\hline & 2016-17 & 2017-18 & 2016-17 & 2017-18 & 2016-17 & 2017-18 & Pooled \\
\hline $\mathrm{I}_{1}=0.6 \mathrm{PE}$ & 128.33 & 112.52 & 6.69 & 6.14 & 117.72 & 106.75 & 112.24 \\
\hline $\mathrm{I}_{2}=0.8 \mathrm{PE}$ & 143.17 & 127.84 & 7.77 & 6.88 & 136.75 & 120.31 & 128.53 \\
\hline $\mathrm{I}_{3}=1.0 \mathrm{PE}$ & 130.17 & 120.01 & 6.92 & 6.38 & 121.74 & 112.43 & 117.08 \\
\hline S.E. \pm & 3.11 & 1.90 & 0.10 & 0.13 & 1.28 & 0.90 & 0.71 \\
\hline C.D. $(\mathrm{P}=0.05)$ & 8.64 & 5.27 & 0.29 & 0.35 & 3.80 & 2.67 & 2.11 \\
\hline \multicolumn{8}{|l|}{ Mulches (M) } \\
\hline $\mathrm{M}_{1}=\mathrm{BPM}$ & 150.56 & 133.96 & 7.88 & 7.13 & 138.55 & 125.61 & 132.08 \\
\hline $\mathrm{M}_{2}=\mathrm{SBPM}$ & 161.78 & 140.58 & 8.58 & 7.49 & 150.98 & 129.43 & 140.21 \\
\hline $\mathrm{M}_{3}=\mathrm{TPM}$ & 124.89 & 115.17 & 6.37 & 6.04 & 112.11 & 106.12 & 109.12 \\
\hline $\mathrm{M}_{4}=$ Control & 98.33 & 90.79 & 5.68 & 5.20 & 99.97 & 91.50 & 95.73 \\
\hline S.E. \pm & 2.47 & 2.01 & 0.15 & 0.20 & 1.80 & 2.45 & 1.75 \\
\hline C.D. $(\mathrm{P}=0.05)$ & 5.19 & 4.22 & 0.31 & 0.43 & 5.35 & 7.26 & 5.20 \\
\hline \multicolumn{8}{|l|}{ I $x M$} \\
\hline S.E. \pm & 4.28 & 3.68 & 0.25 & 0.35 & 3.12 & 4.24 & 3.03 \\
\hline C.D. $(\mathrm{P}=0.05)$ & 9.00 & 7.30 & 0.53 & 0.74 & 9.27 & 12.58 & 9.01 \\
\hline
\end{tabular}

The application of irrigation at $0.8 \mathrm{PE}\left(\mathrm{I}_{2}\right)$ recorded maximum number of fruits per plant, yield per plant and fruit yield $\left(136.75,120.31\right.$ and $\left.128.53 \mathrm{t} \mathrm{ha}^{-1}\right)$ and it was significantly superior to rest of irrigation levels during 2016-17, 2017-18 and pooled mean respectively. Due to adequate amount of irrigation water the higher numbers of fruits per plant was obtained in irrigation level at $0.8 \mathrm{PE}\left(\mathrm{I}_{2}\right)$ which reflects on higher yield per plant and total fruit yield.

The results with respect to various mulch treatment revealed that significantly maximum number of fruits per plant was recorded in silver black polythene mulch (SBPM) as compared to others mulches during both years of experimentation. Further, it was revealed that silver black polythene mulch (SBPM) recorded significantly higher fruit yield per plant and total fruit yield (150.98, 129.43 and 140.21 $\mathrm{t} \mathrm{ha}^{-1}$ ) over the rest of mulch treatment during 2016-17, 201718 and pooled mean respectively however, it was found at par with black polythene mulch (BPM) during 2017-18. The silver black polythene mulch promoted to yield and yield attributes is associated with adequate soil temperature and moisture conservation throughout the growing period of tomato. Similar, kind of results obtained by Harish Kumar et al. (2017) ${ }^{[3]}$ and Rahman et al. (2016) ${ }^{[11]}$ for tomato.

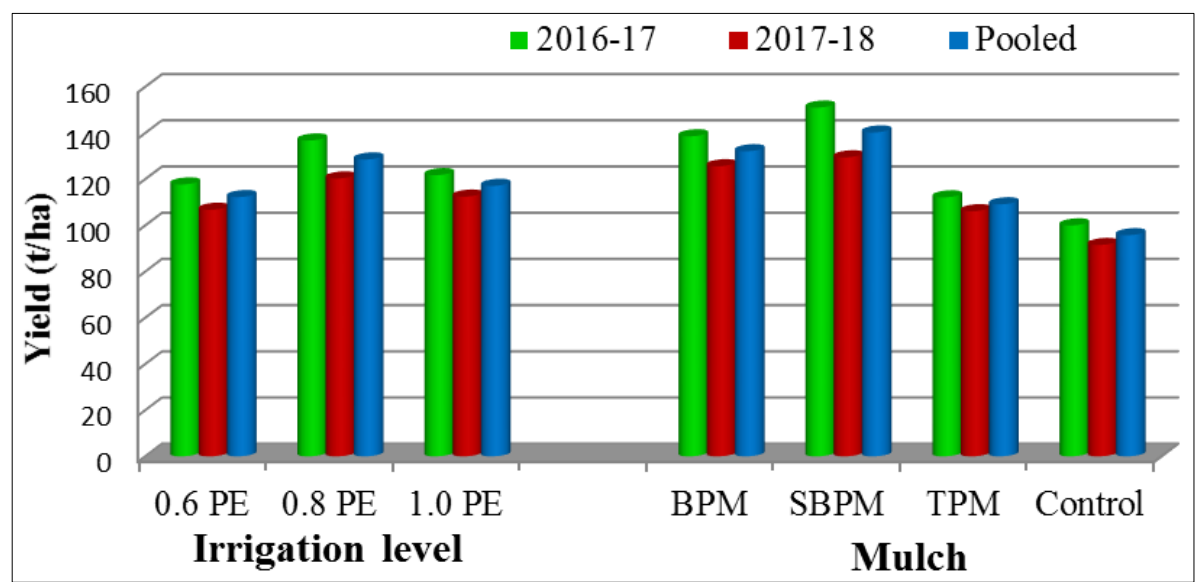

Fig 4: Fruit yield as influenced by different irrigation regimes and mulches during 2016-17 and 2017-18

From Fig. 4 depicted that drip irrigation at $0.8 \mathrm{PE}\left(\mathrm{I}_{2}\right)$ and silver black polythene mulch showed higher fruit yield of tomato during both study years and pooled mean and also showed that it was higher during 2016-17 as compared to 2017-18.
Interaction effect of different irrigation levels and mulches on yield and attributing characters in drip irrigated tomato: As regards to interaction effect of different irrigation regimes and mulches, maximum number of fruits per plant, yield per plant and fruit yield was significantly influenced by various treatment combinations during both the years of experimentation and presented in Tables 4.

Table 4: Yield and yield attributing characters in drip irrigated tomato as influenced by interaction effect of different irrigation levels and mulches during during 2016-17 and 2017-18

\begin{tabular}{|c|c|c|c|c|c|c|c|}
\hline Treatment & Number of fruits per plants & \multicolumn{2}{|c|}{ Yield per plant (Kg) } & \multicolumn{3}{c|}{ Yield (t/ha) } \\
\hline Interaction (I X M) & $\mathbf{2 0 1 6 - 1 7}$ & $\mathbf{2 0 1 7 - 1 8}$ & $\mathbf{2 0 1 6 - 1 7}$ & $\mathbf{2 0 1 7 - 1 8}$ & $\mathbf{2 0 1 6 - 1 7}$ & $\mathbf{2 0 1 7 - 1 8}$ & Pooled \\
\hline $\mathrm{I}_{1} \mathrm{M}_{1}$ & 144.00 & 128.56 & 7.41 & 7.03 & 130.29 & 123.62 & 126.95 \\
\hline $\mathrm{I}_{1} \mathrm{M}_{2}$ & 150.00 & 125.73 & 8.78 & 7.62 & 154.43 & 129.30 & 141.87 \\
\hline $\mathrm{I}_{1} \mathrm{M}_{3}$ & 127.33 & 108.67 & 5.32 & 5.09 & 93.51 & 89.56 & 91.55 \\
\hline $\mathrm{I}_{1} \mathrm{M}_{4}$ & 92.00 & 87.12 & 5.27 & 4.81 & 92.65 & 84.53 & 88.59 \\
\hline
\end{tabular}




\begin{tabular}{|c|c|c|c|c|c|c|c|}
\hline $\mathrm{I}_{2} \mathrm{M}_{1}$ & 154.67 & 142.00 & 8.85 & 7.57 & 155.70 & 133.17 & 144.43 \\
\hline $\mathrm{I}_{2} \mathrm{M}_{2}$ & 169.33 & 153.11 & 8.95 & 8.00 & 157.36 & 137.94 & 147.66 \\
\hline $\mathrm{I}_{2} \mathrm{M}_{3}$ & 137.33 & 120.01 & 7.22 & 6.43 & 127.09 & 113.05 & 120.07 \\
\hline $\mathrm{I}_{2} \mathrm{M}_{4}$ & 111.33 & 96.24 & 6.07 & 5.52 & 106.82 & 97.10 & 101.96 \\
\hline $\mathrm{I}_{3} \mathrm{M}_{1}$ & 153.00 & 131.31 & 7.37 & 6.80 & 129.67 & 120.03 & 124.85 \\
\hline $\mathrm{I}_{3} \mathrm{M}_{2}$ & 166.00 & 142.89 & 8.02 & 6.85 & 141.13 & 121.06 & 131.09 \\
\hline $\mathrm{I}_{3} \mathrm{M}_{3}$ & 110.00 & 116.84 & 6.58 & 6.60 & 115.71 & 115.74 & 115.73 \\
\hline $\mathrm{I}_{3} \mathrm{M}_{4}$ & 91.67 & 89.00 & 5.71 & 5.28 & 100.45 & 92.87 & 96.66 \\
\hline S.E.土 & 4.28 & 3.68 & 0.25 & 0.35 & 3.12 & 4.24 & 3.03 \\
\hline C.D.(P=0.05) & 9.00 & 7.30 & 0.53 & 0.74 & 9.27 & 12.58 & 9.01 \\
\hline
\end{tabular}

Among the various treatment combinations, irrigation level at $0.8 \mathrm{PE}$ with silver black polythene mulch $\left(\mathrm{I}_{2} \mathrm{M}_{2}\right)$ recorded significantly maximum number of fruits per plant over rest of treatment combinations during both the years of study however it was found at par with treatment combination of irrigation level at 1.0 PE with silver black polythene mulch $\left(\mathrm{I}_{3} \mathrm{M}_{2}\right)$ during 2016-17.

Further, the results pertaining to interaction effect of various treatments combination on fruit yield revealed that the application of irrigation level at $0.8 \mathrm{PE}$ with silver black polythene mulch $\left(\mathrm{I}_{2} \mathrm{M}_{2}\right)$ recorded significantly higher fruit yield per plant and total fruit yield of tomato as compared to rest of treatment combinations and it was found at par with irrigation level at $0.8 \mathrm{PE}$ with black polythene mulch $\left(\mathrm{I}_{2} \mathrm{M}_{1}\right)$ and irrigation level at $0.6 \mathrm{PE}$ with silver black polythene mulch $\left(\mathrm{I}_{1} \mathrm{M}_{2}\right)$ during 2016-17, 2017-18 and pooled mean. However, significantly lower fruit yield per plant and total fruit yield of tomato obtained in irrigation level at 0.6 PE with control treatment $\left(\mathrm{I}_{1} \mathrm{M}_{4}\right)$.

The results regarding fruit yield and yield attributing characters revealed that numbers of fruits per plant, yield per plant and total fruit yield were significantly higher in silver black polythene mulch with irrigation level at $0.8 \mathrm{PE}$ might be due to adequate use of irrigation water, optimum soil temperature and moisture conservation results better microclimate which enhance fruit development leading to increase in fruit yield of tomato. The present results are in lined with the findings of Sreedevi et al. (2017) ${ }^{[12]}$ for brinjal who reported that drip irrigation at 0.8 ET with silver black polythene mulch produced significantly maximum yield over control treatment. The present results are parallel to the earlier findings reported by Rajablariani et al. (2012) ${ }^{[10]}$, Choudhary and Bhambri (2013) ${ }^{[2]}$ and Bora and Hanif (2014) ${ }^{[1]}$.

\section{Conclusion}

The results obtained from present study concluded that the use of drip irrigation with lower application of irrigation water i.e at 0.6 PE either with silver black polythene mulch or black polythene mulch improves water use efficiency and inhibited weed growth. The use of silver black polythene mulch or black polythene mulch coupled with drip irrigation at $0.8 \mathrm{PE}$ recorded higher yield attributes along with higher fruit yield of tomato. However, it was comparable with the treatment combination of drip irrigation at $0.6 \mathrm{PE}$ with silver black polythene.

\section{References}

1. Bora NJ, Hanif MB. Drip irrigation and black polyethylene mulch pressure on development, yield and water-use efficacy of tomato. International Journal of Irrigation and Water Management Volume, 4 pages. Available online

www.internationalscholarsjournalsorg. (c) International Scholars Journals 2014.
2. Choudhary VK, Bhambri MC. Crop Productivity, Water Use and Weed Control Efficiency of Capsicum (Capsicum annum L.) Under Drip Irrigation and Mulching. Journal of Agricultural Physics 2013;13:133138.

3. Harish K, Singh AK, Singh P. Effect of Water Regime and Colored Mulches on Productivity of Tomato (Solanum lycopersicon Mill.). Int. J Curr. Microbiol. App. Sci 2017;6(3):1827-1830.

4. Job M, Rusia DK, Dinmani, Singh VK. Effect of drip irrigation and plastic mulch on yield, water use efficiency of cauliflower. Journal of Pharmacognosy and Phytochemistry 2018;SP1:2556-2560.

5. Kashyap S, Phookan DB, Baruah P, Bhuyan P. Effect of drip irrigation and polythene mulch on yield, quality, water-use efficiency and economics of broccoli production. Indian J Hort 2009;66(3):323-325.

6. Kishore G, Maheswara B, Kandpal K, Satishkumar U, Modepalli S. Effect of plastic mulches on the yield, soil temperature and soil moisture of tomato crop. Journal of Pharmacognosy and Phytochemistry 2018;7(5):32763279.

7. Paul JC, Mishra JN, Pradhan PL, Panigrahi B. Effect of drip and surface irrigation on yield, water use-efficiency and economics of capsicum (Capsicum annum L.) grown under mulch and non mulch conditions in eastern coastal India. European Journal of Sustainable Development 2013;2(1):99-108.

8. Reddy GVS, Patil DV, Rao BS, Nagendraprasad B. Effect of different types of irrigation and growing methods on growth, yield and water-use efficiency of tomato (Lycopersicon esculentum Miller). An International Quarterly Journal of Life Science 2015;10(1):243-246.

9. Singh R, Kumar S, Nangare DD, Meena MS. Drip irrigation and black polyethylene mulch influence on growth, yield and water-use efficiency of tomato. African Journal of Agricultural Research 2009;4(12):1427-1430.

10. Rajablariani HR, Hassankhan F, Rafezi R. Effect of colored plastic mulches on yield of tomato and weed biomass. International Journal of Environmental Science and Development 2012;3(6):590-593.

11. Rahman MJ, Quamruzzaman M, Samsuddin M. Effect of different mulch materials on growth and yield of tomato. Bangladesh Hort 2016;2(2):29-37.

12. Sreedevi S, Maheshwara Babu BB, Kandpal K, Satishkumar U, Kanannavar PS. Effect of colour plastic mulching at different drip irrigation levels on growth and yield of brinjal (Solanum melongena L.). J Farm Sci 2017;30(4):525-529. 